\title{
25 Research Square \\ Village Chicken Flock Characteristics and Performances in Western Amhara, Ethiopia
}

Birhan Kassa Gebeyehu ( $\square$ birhankassa56@gmail.com )

ARARI https://orcid.org/0000-0003-1949-8737

\section{Yosef Tadesse}

Haramaya University

\section{Wondmeneh Esatu}

International Livestock Research Institute

\section{Tadelle Dessie}

International Livestock Research Institute

\section{Methodology article}

Keywords: Flock characteristics, Performance, Village chicken

Posted Date: June 11th, 2020

DOI: https://doi.org/10.21203/rs.3.rs-31050/v1

License: (c) (1) This work is licensed under a Creative Commons Attribution 4.0 International License. Read Full License 


\section{Abstract}

\section{Methodology:}

The study was carried out to generate baseline information on village chicken flock characteristics and production performances in South Achefre, Banija and Fagita Lekoma districts of Western Amhara, Ethiopia Multi-stage sampling procedures were employed to select the study villages and respondents and then nine villages were selected purposively. The 180 participants were chosen by random sampling techniques for qualitative and quantitative research. Data were collected by individual survey using open data kit. The collected data were analyzed using General Linear Model (GLM) of SAS software version 9.1 and Duncan Multiple Range Test (DMART) was also used to locate treatment means that were significantly different.

\section{Result}

From the flock composition the Hen contributes the highest proportion (39.2\%) followed by Chicks (31.2\%). Mean sexual maturity of local Hen and Cock was $24.95 \pm 0.269$ and $23.56 \pm 0.36$ weeks, respectively. Mean egg production performance of local chickens in the study area was $14.89 \pm 0.36$ per clutch with a clutch length of $23.98 \pm 0.61$ and $2.47 \pm 0.07$ clutch cycle per year.

\section{Conclusion}

The production performance of indigenous chicken and their survival performance in the study area are low to medium. Therefore, in order to improve production and survival performance, appropriate interventions in terms of supplementary feeding, selection and disease control are important strategies.

\section{Introduction}

In Ethiopia, the agricultural sector is a corner stone of the economic and social life of the people. The livestock sector in Ethiopia contributes 12 and $33 \%$ of the total and agricultural Gross Domestic Product (GDP), respectively, and support livelihood of $65 \%$ of the population [1]. The sector also accounts for $12-$ $15 \%$ of the total export earnings [2]. The diverse agro-ecology and agronomic practice prevailing in the country together with the huge population of livestock in general and poultry in particular, could be a promising attribute to boost up the livestock sector and increase its contribution to the total agricultural output as well as to improve the living standards of the poor livestock keepers [3]. Poultry production, as one segment of livestock production, has a peculiar privilege to contribute to the sector. Poultry in Sub Saharan African countries is a source of self-reliance for women since, poultry and egg sales are decided by women both of which provide women an immediate income to meet household expenses and sources of food [4]. In Ethiopia, chicken production is practiced in nearly all poor rural smallholder households [5]. Chicken production is practiced in both traditional and modern production systems in which the former is 
most widespread and almost every rural family owns chicken, which provides valuable sources of family protein and income [5]. It is cheap to produce, require little investment, used for food and religious celebrations under the smallholder farmers of the country [6]. The total chicken population in Ethiopia is estimated at 60.51 million [7], with regard to breed, 94.33 percent of the total poultry were indigenous chickens, while the remaining 3.21 and 2.47 percent of the total poultry were reported to be hybrid and exotic, respectively. Ethiopia's chicken industry, which is still in its infancy, holds considerable potential for growth, especially when considering that average per capita poultry consumption of 0.5 kilogram is among the lowest in the world and by comparison, Per capita consumption in Sub-Saharan Africa is 2.3 kilogram [8]. Assessment of flock characteristics and performance is important for considerable relevance in intervention research and development directions and strategies. Therefore, the objective of the study was to understand the flock characteristics and performances under their production system.

\section{Materials And Methods}

\section{Area description}

The study was conducted in three districts of Western Amhara, Ethiopia namely South Achefere, Banija and Figita Lekoma. These districts were selected based on number of chickens, number of households rearing chicken, availability of feed resources for chicken and strategically selected for their accessibility and safe for research work. South Achefer district is found in West Gojam administrative zone of Amhara National Regional State. It lies $11^{\circ} 04^{\prime}-11^{\circ} 05^{\prime}$ North latitude and $36^{\circ} 52^{\prime}-36^{\circ} 54^{\prime}$ East longitude with an altitude of 1500-2600 meters above sea level. The total annual rainfall is ranges from $1365-1623 \mathrm{~mm}$ and the temperature is ranged from 11.8 to $28.4{ }^{\circ} \mathrm{C}$ [9]. Banija district is found in Awi Zone administrative zone of Amhara National Regional State. The district lies within $11.36^{\circ}$ to $12^{0} 09^{\prime}$ North latitude and $36^{0} 95^{\prime}-38^{0} 95^{\prime}$ East and the altitude of the study area ranges from 1800 to 2953 Meter above sea level. The mean annual rainfall of the study area ranges from $1700 \mathrm{~mm}$ to $2560 \mathrm{~mm}$, with mean monthly minimum and maximum temperature ranging from $7^{\circ} \mathrm{C}$ to $12^{\circ} \mathrm{C}$, and $20^{\circ} \mathrm{C}$ to $25^{\circ} \mathrm{C}$, respectively [9]. Fagita Lekoma district is found in Awi Zone administrative zone of Amhara National Regional State. The district is located at $10^{0} 52^{\prime}$ to $11^{\circ} 03^{\prime}$ North latitude and $36^{\circ} 38^{\prime}$ to $37^{\circ} 8^{\prime}$ East longitudes and altitude ranges from 2000-3200 $\mathrm{m}$ above sea level. The average annual rainfall of the district is $2379 \mathrm{~mm}$. Temperature varies between the mean annual maximum of $25^{\circ} \mathrm{C}$ and mean annual minimum of $11^{\circ} \mathrm{C}$ across the elevation gradient [9].

\section{Sampling technique and sample size}

Multi-stage sampling technique (purposive and random) was applied for the selection of both villages and participants in each district, respectively. Villages were selected based on number of chickens, number of households rearing chicken, availability of feed resources for chicken and for their accessibility and safe for research work. Based on those criteria three villages per district and a total of nine villages in the three districts were selected. Computerized random sampling procedures were applied 
to select 20 village chicken producer's households in each village and a total of 180 households were selected.

\section{Methods and type of data collection}

A structured questionnaire survey tool was developed, tested and implemented using Open Data Kit (ODK) data collection tool. The major quantitative data collected during the survey were flock size and composition, flock performance (such as age of sexual maturity, clutch size per year, egg production per clutch, clutch length, number of times the hen hatches in a year, number of eggs set per brood, number of chicks hatched per brood and chick livability to adulthood per brood).

\section{Statistical analysis}

The collected data were analyzed using appropriate statistical analysis procedures. Descriptive statistics and cross-tabulations were employed where they are appropriate. The General Linear Model (GLM) of SAS software version 9.1, on qualitative variables was used. The Duncan Multiple Range Test (DMART) was also used to locate treatment means that were significantly different.

\section{Results And Discussion}

\section{Flock size and composition per household}

The overall mean number of total chicken per household was significantly different $(p<0.001)$ among the study districts. The overall mean total number of chickens per household across the study districts was $7.40 \pm 0.57$ (Table 1). The average number of chicken per household was higher in south Achefere than Banija district and it was related to the presence of more scavenging space in the household garden and the ability of respondents to give supplementary feed for their chicken. Similarly, chicken producers in South Achefre district were mainly keeping chicken for adult chicken sale. Therefore, a higher number of hens and chicks per household could be higher to rear up to reach marketable weight. This result was in line with the report of [10] explained that the overall mean flock size per household was 7.13 in north western Amhara, but lower than the report of [11] 13 and 12 chicken per household in Burie and Fogera districts of north western Amhara, respectively and [12] 9.22 chicken per household in Southern Ethiopia. Difference in flock size might be differences in scavenging space owned by the household, season during the study, availability of feed resource and supplementary feed.

There was a significant $(p<0.05)$ difference in the number of local chicken owned per household among the study districts which were higher in South Achefere district than Banija and Fagiata Lekoma which is related to feed access and scavenging space. The overall mean number of local chicken per household was $6 \pm 0.49$ (Table 1). The result was higher than the mean local chicken reported in Dawo and Seden Sodo districts of Southwest Showa Zone of Oromia region and Mehale Amba and Mehurena Aklil districts of Gurage zone, southern region with the flock size of 5.41, 4.11, 5.13 and 4.75 chicken per household, respectively [13]. But higher result was reported by [14] which were on average 24 chicken per 
household in Western zone of Tigray. The mean number of local cocks which were used for breeding purpose in South Achefere district was significantly higher than Banija district. This result indicates that a chicken producer in Banija district uses common cock in a village.

Table 1: Flock size and composition per household in the study area (Mean $\pm \mathrm{SE}$ )

\begin{tabular}{|c|c|c|c|c|c|}
\hline \multirow[t]{2}{*}{ Flock size (Number) } & \multicolumn{3}{|l|}{ District } & \multirow[t]{2}{*}{ Overall mean } & \multirow[t]{2}{*}{ Significance level } \\
\hline & South Achefer $(\mathrm{N}=60)$ & Banija $(\mathrm{N}=60)$ & Fagita Lekoma $(\mathrm{N}=60)$ & & \\
\hline Total chicken & $10.71^{\mathrm{a}} \pm 1.15$ & $4.65^{\mathrm{b}} \pm 0.56$ & $6.83^{\mathrm{ab}} \pm 0.98$ & $7.40 \pm 0.57$ & $* * *$ \\
\hline Cock & $0.77 \pm 0.12$ & $0.42 \pm 0.08$ & $0.67 \pm 0.13$ & $0.60 \pm 0.06$ & NS \\
\hline Hen & $2.77^{\mathrm{ab}} \pm 0.18$ & $2.42^{\mathrm{b}} \pm 0.22$ & $3.70^{\mathrm{a}} \pm 0.61$ & $2.96 \pm 0.23$ & $* *$ \\
\hline Cockerels & $1.22^{\mathrm{a}} \pm 0.28$ & $0.23^{\mathrm{b}} \pm 0.09$ & $0.20^{\mathrm{b}} \pm 0.11$ & $0.55 \pm 0.11$ & $* * *$ \\
\hline Pullets & $1.53^{\mathrm{a}} \pm 0.25$ & $0.33^{\mathrm{b}} \pm 0.10$ & $0.65^{\mathrm{b}} \pm 0.19$ & $0.84 \pm 0.12$ & $* * *$ \\
\hline Chick & $4.43^{\mathrm{a}} \pm 0.76$ & $1.28^{\mathrm{b}} \pm 0.44$ & $1.67^{\mathrm{b}} \pm 0.47$ & $2.46 \pm 0.35$ & $* * *$ \\
\hline Local chicken & $9.9^{\mathrm{a}} \pm 1.12$ & $3.58^{\mathrm{b}} \pm 0.51$ & $4.48^{\mathrm{b}} \pm 0.58$ & $6 \pm 0.49$ & $* * *$ \\
\hline Cock & $0.7^{\mathrm{a}} \pm 0.11$ & $0.3^{\mathrm{b}} \pm 0.06$ & $0.5^{\mathrm{ab}} \pm 0.09$ & $0.5 \pm 0.05$ & $* * *$ \\
\hline Hen & $2.5^{\mathrm{a}} \pm 0.17$ & $1.9^{\mathrm{a}} \pm 0.17$ & $2.4^{\mathrm{a}} \pm 0.32$ & $2.3 \pm 0.14$ & NS \\
\hline Cockerels & $1.1^{\mathrm{a}} \pm 0.27$ & $0.2^{\mathrm{b}} \pm 0.09$ & $0.1^{\mathrm{b}} \pm 0.09$ & $0.5 \pm 0.11$ & $* * *$ \\
\hline Pullets & $1.4^{\mathrm{a}} \pm 0.22$ & $0.3^{b} \pm 0.08$ & $0.3^{\mathrm{b}} \pm 0.09$ & $0.7 \pm 0.09$ & $* * *$ \\
\hline Chick & $4.1 \pm 0.76$ & $1.0^{\mathrm{b}} \pm 0.40$ & $1.1^{\mathrm{b}} \pm 0.36$ & $2.07 \pm 0.32$ & $* * *$ \\
\hline Exotic chicken & $0.17 \pm 0.15$ & $0.28 \pm 0.92$ & $0.68 \pm 0.30$ & $0.38 \pm 0.12$ & NS \\
\hline Cock & $0.03 \pm 0.02$ & $0.60 \pm 0.24$ & $0.02 \pm 0.13$ & $0.02 \pm 0.01$ & NS \\
\hline Hen & $0.2 \pm 0.12$ & $2.8 \pm 1.02$ & $0.5 \pm 0.27$ & $0.24 \pm 0.10$ & NS \\
\hline Pullets & $0.05 \pm 0.05$ & $0.03 \pm 0.17$ & $0.10 \pm 0.07$ & $0.50 \pm 0.03$ & NS \\
\hline Chick & $0.05 \pm 0.05$ & $0.07 \pm 0.07$ & $0.10 \pm 0.07$ & $0.07 \pm 0.04$ & NS \\
\hline Cross breed & $0.65 \pm 0.27$ & $0.78 \pm 0.28$ & $1.67 \pm 0.52$ & $1.03 \pm 0.22$ & NS \\
\hline Cock & $0.03 \pm 0.05$ & $0.13 \pm 0.05$ & $0.17 \pm 0.04$ & $0.09 \pm 0.02$ & NS \\
\hline Hen & $0.20 \mathrm{~b} \pm 0.08$ & $0.32^{\mathrm{ab}} \pm 0.09$ & $0.82^{\mathrm{a}} \pm 0.22$ & $0.44 \pm 0.09$ & $* * *$ \\
\hline Male grower & $0.08 \pm 0.05$ & $0.05 \pm 0.03$ & $0.07 \pm 0.07$ & $0.07 \pm 0.03$ & NS \\
\hline Female grower & $0.08 \pm 0.06$ & $0.06 \pm 0.04$ & $0.21 \pm 0.13$ & $0.12 \pm 0.05$ & NS \\
\hline Chick & $0.25 \pm 0.14$ & $0.25 \pm 0.19$ & $0.45 \pm 0.23$ & $0.32 \pm 0.11$ & NS \\
\hline
\end{tabular}

${ }^{a}, b$ Means within a row followed by different superscripts show the presence of significant differences $(P<0.05), * * * P<0.001, * * P<0.01, N S($ Nonsignificant)

The flock composition (flock composition is the percentage of each flock age category from the total flock) of Banija and Fagita Lekoma districts was dominated by Hens followed by Chicks whereas, in South Achefere district, the flock composition was dominated by Chicks and followed by Hens (figure 1). The overall mean composition of flocks in the study area was dominated by Hens followed by Chicks. Keeping of higher proportion of Hens and Chicks could be to produce higher number of egg for market sale, household consumption and hatching for stock replacement for a sustainable manner and to grow Chicks for live adult chicken sale. The lower proportion of Cocks and male growers observed within the flock in the study was in agreement with report of [15] and [16] and this might be attributed to the selling of cockerels for income generation. The cock hen ratio was calculated based on the number of breeding hens and cocks available during the study period and in the study village. Based on that the average breeding male to breeding female ratio are 1:3.51, 1:9.4 and 1:4.8 in South Achefer, Banija and Fagita 
Lekoma district, respectively. In this regard the recommended cock to hen ratio in light breed is 1:8-10 [17]. In South Achefere and Banija district, the cocks were underutilized and there is the need to eliminate some by either selling or consuming them to ensure proper utilization of cocks. This could be attributed to the lack of knowledge on chicken husbandry and breeding management.

\section{Productive and Reproductive Performance of Chicken}

The productive and reproductive performances of local, exotic and cross (local x exotic) chicken breeds under the village production system are indicated in Table 2 and 3. Age of sexual maturity of female chicken, average number of days per clutch (clutch is the time between that the hen starts to lay egg and come up with broody), average number of eggs per brood, number of chicks hatched per brood and number of chicks surviving to weaning per brood of local hens were significantly different among the study district.

\section{Age of sexual maturity}

Age of sexual maturity of female chicken for Banija and Faguta Lakuma districts were higher than south Achefer district. The overall mean age of sexual maturity of local hen was $24.95 \pm 0.269$ weeks. The result showed that pullets in South Achefere district had relatively matured faster than chicken of the other districts. Differences might be ecotype difference which is Mecha chicken ecotype in South Achefre and Tilli chicken ecotype in Banija and Fagita Lekoma and or management in supplementary feed and availability of scavenging resources. The current result is in line with 5.5 months reported by [10] in western Amhara, respectively, for village chickens. Contrary to this study, indigenous village chickens in Eastern Gojjam zone attained their sexual maturity at an average of 7 months [18] and 6.8 months [5].

The overall mean age of sexual maturity for local male chicken was $23.56 \pm 0.36$ weeks (Table 2). Similarly, [10] reported that the majority of local cocks in northwest Ethiopia reach sexual maturity between 20-24 weeks of age. This finding is also comparable with the findings of [18] in which the average age of the cock at first mating was $4.7 \pm 0.58$ months, and 5.71 month reported by [14] for male in western zone of Tigray. There was significant variation between local, exotic and crossbreed chickens in terms of age of sexual maturity of hen and cock (Table 3 ). Exotic and crossbreed male and female chicken were early mature than local chickens. Difference in age of sexual maturity could be due to genotypic differences.

\section{Egg production per clutch}

The overall mean number of egg production for local hen/clutch in the three districts was $14.89 \pm 0.36$ (Table 2). The result is in line with the report of [11] in which mean number of egg production per local hen per clutch was $15.7 \pm 3.2$ and 13.2 in Burie and Fogera districts of north western Amhara, respectively, but higher than those reported by [3] and [19] in which the mean egg number laid per clutch per hen of local chickens in north Wollo zone, north Gondar Amhara region and Ethiopia were 12.64, $11.53,(8-15)$ and 12 (national average of egg yield/hen/clutch), respectively. But it was lower as 
compared with findings of [5] reported 17.7 eggs in five agro-ecological zones of Ethiopia, and [20] reported 16.6 eggs in Fogera district. Variation in egg production could be due to number of clutches, inter brooding length and average day for weaning young chicken and unknown genetic factors associated with the local breed [12]. In general, the annual egg production in a flock is a function of egg production per hen per clutch, clutch length and the proportion of matured hens in a flock which are a function of management. Long clutch length in the study areas contributes for higher number of eggs per clutch.

There was significance variation between local, cross and exotic chickens with regard to mean egg production per clutch (Table 3 ). The current result revealed that the numbers of eggs produced/clutch/hen was higher for exotic and cross breed chickens as compared to that of local chickens. Indigenous chickens are generally known to lay fewer eggs as compared to exotic chickens. Variation among those breeds in egg production could be genotypic differences. The result of the present study is lower than the report of [21] who found egg production per clutch of 31.66 and 26.14 for cross and exotic respectively, but higher than 11.23 for indigenous chickens in Nole Kobba woreda.

\section{Clutch length}

The mean clutch length for local chicken was highly significantly $(p<0.01)$ different among the study districts (Table 2) and mean number of days per clutch in Banija and Fagita Lekoma district was significantly higher than South Achefer district and the overall mean number of days per clutch in the districts was $23.98 \pm 0.61$. The average length of egg-laying period per hen was also determined by breeds and management systems and the estimated numbers of days were 21, 36 and 105 days for local, hybrid and exotic breeds, respectively [23].

\section{Clutch size}

The overall mean of clutch size per year for local hen was $2.47 \pm 0.07$ which is comparable with that of 2 to 3 clutches per hen per year (Halima, 2007) in western Amhara but lower than 3.83 per year [11] in Burie district, 3.7 [12] in Dale, Wonsho and Loka Abaya Woredas of Southern Ethiopia and 4.12 [24] in Lemo district, Hadiya Zone. The variation could be attributed to the genetic make-up of the local chickens, environmental factors and management practices provided by the chicken producers $[25 ; 26]$.

\section{Number of eggs set per brood and number of chicks hatched per brood}

Mean number of eggs set per brood and number of chicks hatched per brood in Fagita Lekoma and Banija districts were significantly higher than South Achefer district and the overall mean of number of eggs set per brood and hatched per brood in the three districts were 13.89 \pm 0.22 and $11.91 \pm 0.24$ (Table 2). The current result is higher than the finding of [12] in which on average number of eggs per set and number of chicks hatched per set were 11.18 and 9.33 respectively. These differences could be attributed to season of incubation, brooding experience, availability of eggs, size of eggs, body size of broody hen and her maternal instinct behavior [17]. These traits are known to determine the number of eggs placed per brooding hen [22]. According to [15] and [22], hatchability of eggs and the survival rate of the hatched 
chicken are among the major factors that determine the productivity of chicken. The current finding was higher than 10.0 the result reported by [25] and [27] in southern Ethiopia, 8.1 reported by [15] in Ethiopia and 8.7 by [17] for Ghana in number of eggs hatched per brood.

\section{Number of chicks surviving up to weaning}

Mean number of chicks surviving to weaning per brood in Fagita Lekoma was significantly higher than South Achefer and Banija districts and on average, out of the hatched chicks in the present study only $7.63 \pm 0.23$ chicks survived. This result was similar with 7.1 chicks that survived [27] but higher than the 5.5 chicks that survived as reported by [25].

\section{Hatchability}

The overall mean of hatchability of local brooding hen was $85.75 \%$ (Table 2). This result is comparable to $82.8 \%$ of the result reported by [28] in east Gijam. The percentage of survival rate of chicks to adulthood was $61.09 \%$ in South Achefre, $60.49 \%$ in Banija and $67.46 \%$ in Fagita Lekoma districts with the overall mean of $64.06 \%$. The higher survivability indicates that the lower mortality rate. The current result is better than the finding of [15] who reported $41 \%$ of chick mortality for indigenous chickens in Gomma woreda. The reason behind the mortality rate difference could be management differences among chicken keepers. Hatchability depends on instinct maternal behavior of the hen, degree of management of the hen during brooding and prevalence of predators [22]; [17] while the survival rate of the hatched chicks depends on the prevalence of predation and disease [17].

Table 2. Least square mean (Mean \pm SE) of productive and reproductive performances of chicken under village production system

\begin{tabular}{|c|c|c|c|c|c|}
\hline \multirow[b]{2}{*}{$\mathrm{t}$} & \multicolumn{3}{|c|}{ District } & \multirow[t]{2}{*}{ Overall mean } & \multirow{2}{*}{$\frac{\text { Significance }}{\text { level }}$} \\
\hline & South Achefer & Banija & Fagita Lekoma & & \\
\hline \multicolumn{6}{|l|}{ al chicken } \\
\hline of sexual maturity for female (weeks) & $23.83^{\mathrm{b}} \pm 0.52$ & $25.58^{\mathrm{a}} \pm 0.54$ & $25.20^{\mathrm{ab}} \pm 0.44$ & $24.95 \pm 0.269$ & $* *$ \\
\hline of sexual maturity for male (weeks) & $22.79 \pm 0.53$ & $23.75 \pm 0.58$ & $23.87 \pm 0.61$ & $23.56 \pm 0.36$ & NS \\
\hline in number of eggs per clutch & $14.56 \pm 0.68$ & $15.03 \pm 0.69$ & $14.98 \pm 0.56$ & $14.89 \pm 0.36$ & NS \\
\hline ch length & $20.96^{b} \pm 0.97$ & $25.62^{\mathrm{a}} \pm 1.04$ & $24.57^{\mathrm{a}} \pm 0.96$ & $23.98 \pm 0.61$ & $* * *$ \\
\hline n number of eggs set per brood & $12.76^{\mathrm{b}} \pm 0.46$ & $13.79^{\mathrm{ab}} \pm 0.37$ & $14.58^{\mathrm{a}} \pm 0.31$ & $13.89 \pm 0.22$ & $* * *$ \\
\hline aber of chicks hatched per brood & $11 \pm 0.47 \mathrm{~b}$ & $11.62^{\mathrm{ab}} \pm 0.39$ & $12.60^{\mathrm{a}} \pm 0.37$ & $11.91 \pm 0.24$ & $* *$ \\
\hline of times the hen hatches in a year & $2.60 \pm 0.11$ & $2.46 \pm 0.13$ & $2.40 \pm 0.13$ & $2.47 \pm 0.07$ & NS \\
\hline aber of surviving chicks at weaning & $6.72^{\mathrm{b}} \pm 0.38$ & $7.03^{b} \pm 0.33$ & $8.50^{\mathrm{a}} \pm 0.36$ & $7.63 \pm 0.23$ & $* * *$ \\
\hline chability (\%) & $86.21^{\mathrm{a}}$ & $84.76^{\mathrm{b}}$ & $86.42^{\mathrm{a}}$ & 85.75 & \\
\hline rival ability up to adulthood (\%) & $61.09^{b}$ & $60.49^{\mathrm{b}}$ & $67.46^{\mathrm{a}}$ & 64.06 & $* *$ \\
\hline \multicolumn{6}{|l|}{ tic chicken } \\
\hline of sexual maturity of hens (weeks) & 20 & $20 \pm 0.50$ & $22.14 \pm 1.09$ & $21.68 \pm 0.83$ & NS \\
\hline of sexual maturity of cocks (weeks) & 24 & $21.67 \pm 1.20$ & $22 \pm 0.64$ & $22 \pm 0.58$ & NS \\
\hline n number of eggs per clutch & NA & 25 & 25 & 25 & NS \\
\hline \multicolumn{6}{|l|}{ ss breed chicken } \\
\hline of sexual maturity of hens (weeks) & 24 & $21.60 \pm 0.98$ & $23.47 \pm 0.66$ & 23.214 & NS \\
\hline of sexual maturity of cocks (weeks) & $23 \pm 1$ & $21 \pm 0.63$ & $21.47 \pm 0.47$ & 21.607 & NS \\
\hline in number of eggs per clutch & $26.67 \pm 3.33$ & $22.38 \pm 2.69$ & $27.36 \pm 0.95$ & 25.454 & NS \\
\hline
\end{tabular}


a, ${ }^{b}$ Means within a row followed by different superscripts show the presence of significant differences $(P<0.05), * * * P<0.001, * * P<0.01, \quad N S(N o n-$ significant

Table 3. Least square mean (Mean \pm SE) of productive and reproductive performances of chickens under village production system

\begin{tabular}{|l|c|c|c|c|}
\hline \multirow{2}{*}{ uit } & \multicolumn{3}{|c|}{ Breed } & Significance \\
\cline { 2 - 4 } & Local & Exotic & Cross breed & level \\
\hline 2 of sexual maturity of hens (weeks) & $24.95^{\mathrm{a}} \pm 0.29$ & $21.68^{\mathrm{b}} \pm 0.82$ & $22.90^{\mathrm{b}} \pm 0.53$ & $* * *$ \\
\hline 2 of sexual maturity of cocks (weeks) & $23.56^{\mathrm{a}} \pm 0.36$ & $22^{\mathrm{ab}} \pm 0.59$ & $21.31^{\mathrm{b}} \pm 0.45$ & $* * *$ \\
\hline an number of eggs per clutch & $14.89^{\mathrm{b}} \pm 0.37$ & $25^{\mathrm{a}} \pm 0.00$ & $23.94^{\mathrm{a}} \pm 1.98$ & $* * *$ \\
\hline
\end{tabular}

${ }^{a, b}$ Means within a row followed by different superscripts show the presence of significant differences $(P<0.05), * * * P<0.001, * * P<0.01, \quad N S(N o n-$ significant)

\section{Constraints of chicken Production in the study area}

Constraints of chicken production in the study area are presented in graph two. According to the survey result lack of improved breed (0.188), disease occurrence (0.185), lack of veterinary service $(0.151)$ and poor extension service $(0.117)$ were major constraints of chicken production. In line with the current result, Halima reported that diseases and predators were a major factor that causes loss of chicken in Northwest Ethiopia. Predators like a hawk, wild animals and cat were main cause of mortality in the study area. As observed in transect walk farmers tie hen in and around the gate with rope to reduce the loss of young chicken with predator.

\section{Summary And Conclusion}

Hens and young chicken were the dominant class of chickens in the flock structure of the study area, indicating that the intention of farmers could be for egg production for selling and hatching for stock replacement. Local hens and cocks in the study area were reached at sexual maturity at lately $(24.95 \pm$ 0.269 and $23.56 \pm 0.36$ weeks respectively) than exotic hens and exotics cocks have had reach earlier at $21.68 \pm 0.83$ and $22 \pm 0.58$ weeks, respectively due to genotypic potential difference. The mean egg production of local chickens in the study area was $14.89 \pm 0.36$ eggs per hen per clutch with clutch length of $23.98 \pm 0.61$ days and the number of clutches per year was $2.47 \pm 0.07$ which is lower than improved chickens. Average number of eggs set per brood, hatched and number of chicks surviving to adulthood in the study was $13.89 \pm 0.22,11.91 \pm 0.24$ and $7.63 \pm 0.23$ with hatchability and survivability percentage of 85.75 and 64.06 , indicating high mortality rate.

In general, the production performance of local chicken and their survival performance in the study area are low to medium. To increase the performance of village chicken production, appropriate innervations are crucial. Therefore, in order to improve production and survival performance, manage-mental interventions (feeding, housing and husbandry) and or genetic improvements (selection and or cross breeding) are extremely important to be considered for the chicken production program. 


\section{Declarations}

\section{ACKNOWLEDGMENT}

We are thankful to Bill and Melinda Gates Foundation for financing this work under the auspices of the International Livestock Research Institute (ILRI). We also thank Ethiopia institute of Agricultural Research, Amhara regional Agricultural Research institute and the farmers that participate in this study.

\section{Funding}

Research supported by Bill and Melinda Gates Foundation.

\section{Data Availability}

The data used to support the findings of this study are available from the corresponding author upon request.

\section{Availability of data}

The datasets analysed in the current study are available from the corresponding author on request.

\section{Contribution}

Birhan kassa participated in conceiving and coordinating the overall activity, and carried out the statistical analysis, and drafted the manuscript. Dr. Yosef Tadesse Participated in drafting and reviewing the manuscript and Dr. Wondmeneh Esatu and Dr. Tadelle Dessie participated in the design of the study and reviewing the manuscript

\section{Ethics approval and consent to participate}

Not Applicable

\section{Consent for publication}

Not applicable.

\section{Competing interests}

The authors declare that they have no competing interests

\section{References}

1. Food and Agriculture Organization of the United States online statistical. Food and Agriculture Organization of the United States online statistical database. 2013; http://faostat3.fao.org/compare/E. 
2. Tewodros M, Mesert M, Merkebu G. Assessment of livestock genetic resource diversity in Ethiopia: An implication for conservation. Journal of Gene $c$ and Environmental Resources Conservation. 2015.

3. Addisu G, Hailu M, Zewdu W. Indigenous Chicken Production System and Breeding Practice in North Wollo, Amhara Region, Ethiopia. Poultry Fisheries Wild Life Science. 2013;1:108.

4. Missohou A, Dieye P, Taliki E. Rural Poultry Production and Productivity in Senegal. Livestock Research for Development. 2002; 14 (2).

5. Tadelle Dessie. Phenotypic and genetic characterization of chicken ecotypes in Ethiopia Tadelle Dessie. Phenotypic and genetic characterization of chicken ecotypes in Ethiopia. Thesis PhD, Humboldt University, Germany. 2003.

6. Tadelle D, Ogle B. Village poultry production system in the central highlands of Ethiopia. Trop Anim Health Prod. 2001;33(6):521-37.

7. CSA. Agricultural sample survey $2015 / 2016$, vol. II. Report on livestock and livestock characteristic, bulletin 583. 2016.

8. USDA. Ethiopia's Demand for Chicken Meat is Expected to Grow. Report. Global Agricultural Information Network. 2017.

9. CSA. Agricultural sample survey volume 2 report on livestock and livestock characteristics. 2008.

10. Halima H. Phenotypic and genetic characterization of indigenous chicken populations in North-West Ethiopia. Ph.D Thesis. Submitted to the faculty of natural and agricultural sciences department of animal, wildlife and grassland Sciences. University of the Free State, Bloemfontein, South Africa. 2007.

11. Fissha M, Azage T, Tadelle D. Indigenous chicken production and marketing systems in Ethiopia: Characteristics and opportunities for market-oriented development. IPMS (Improving Productivity and Market Success) of Ethiopian Farmers Project Working Paper 24. Nairobi, Kenya, ILRI. 2010.

12. Mekonnen G. Characterization of smallholder poultry production and marketing system of Dale, wonsho and Loka Abaya Weredas of Southern Ethiopia. 2007; p: 111.

13. Emebet M. Phenotypic and genetic characterization of indigenous chicken in southwest showa and gurage zones of Ethiopia. A dissertation submitted to the College of Veterinary Medicine and Agriculture of Addis Ababa University in partial fulfillment of the requirements for the degree of Doctor of Philosophy in Animal Production. Addis Ababa, Ethiopia. 2015.

14. Shishay M, Brhanu B, Tadelle D. Village chicken breeding practices, objectives and farmers' trait preferences in western zone of Tigray, Northern Ethiopia. Journal of Agricultural Research Development. 2016;6(1):001-11.

15. Meseret M. Characterization of village chicken production and marketing system in gomma wereda, jimma zone, Ethiopia. M.Sc thesis, Jimma University, Jimma, Ethiopia. 2010.

16. Hunduma D, Regassa C, Fufa D, Endalew B, Samson L. Major Constraints and Health Management of Village Poultry Production in Rift Valley of Oromia, Ethiopia. American-Eurasian Journal of Agriculture Environmental Science. 2010;9:529-33. 
17. Hagan JK, Bosompem M, Adjei IA. The productive performance of local chickens in three ecological zones of Ghana. Asian Research Publishing Network (ARPN). Journal of Agriculture Biology Science. 2013;8(1):51-6.

18. Melkamu B, Andargie Z. Performance evaluation of local chicken at Enebsie Sar Midir Woreda, Eastern Gojjam, Ethiopia. Journal of Agricultural Science. 2013;1(2):006-10.

19. CSA. Agricultural sample survey. Report on livestock and livestock characteristic. 2003.

20. Bogale W. On farm phenotypic characterization of indigenous chicken ecotypes, breeding and husbandry practices in west Hararghe zone, Oromia region, Ethiopia. Msc thesis, Haramaya University, Haramaya, Ethiopia. 2017.

21. Ndiilokelwa P. Characterization and production performance of indigenous chickens in Northern Namibia regions. A dissertation submitted to the University of Namibia. 2011.

22. Matiwose H, Negassi A, Solomon D. Production performance of local and exotic breeds of chicken at rural household level in Nole Kabba Woreda, Western Wollega, Ethiopia. African journal of Agricultural Research. 2013;8(11):1014-21.

23. CSA. Summary and statistical report of the 2007 population and housing census, federal democratic republic of Ethiopia, population census commission, Addis Ababa. 2011.

24. Salo S, Gebrela T. and Demissie. Village Chicken Production System and Constraints in Lemo District, Hadiya Zone, Ethiopia. Poultry Fish Wild life Science. 2016;4:158. doi:10.4172/2375446X.1000158.

25. Melese G, Melkamu B. Assessment of Chicken Production under Farmers Management Condition in East Gojam Zone, Amhara Regional State, Ethiopia. Greener Journal of Animal Breeding Genetics. 2014;1(1):001-10.

26. Guni FS, Katule AM, Mwakilembe PAA. Characterization of local chickens in selected districts of the Southern Highlands of Tanzania: II. Production and Morphometric traits. Journal of Livestock Research and Rural development. 2013; 25(11).

27. Gebreegziabher Z, Tsegay L. Production and reproduction performance of local chicken breeds and their marketing practices in Wolaita Zone, Southern Ethiopia. African Journal of Agricultural Research. 2016.

28. Nigatu M, Bezabih M. Assessment of Chicken Production under Farmers Management Condition in East Gojam Zone, Amhara Regional State, Ethiopia. Greener Journal of Animal Breeding Genetics. 2014;1(1):001-10.

\section{Figures}




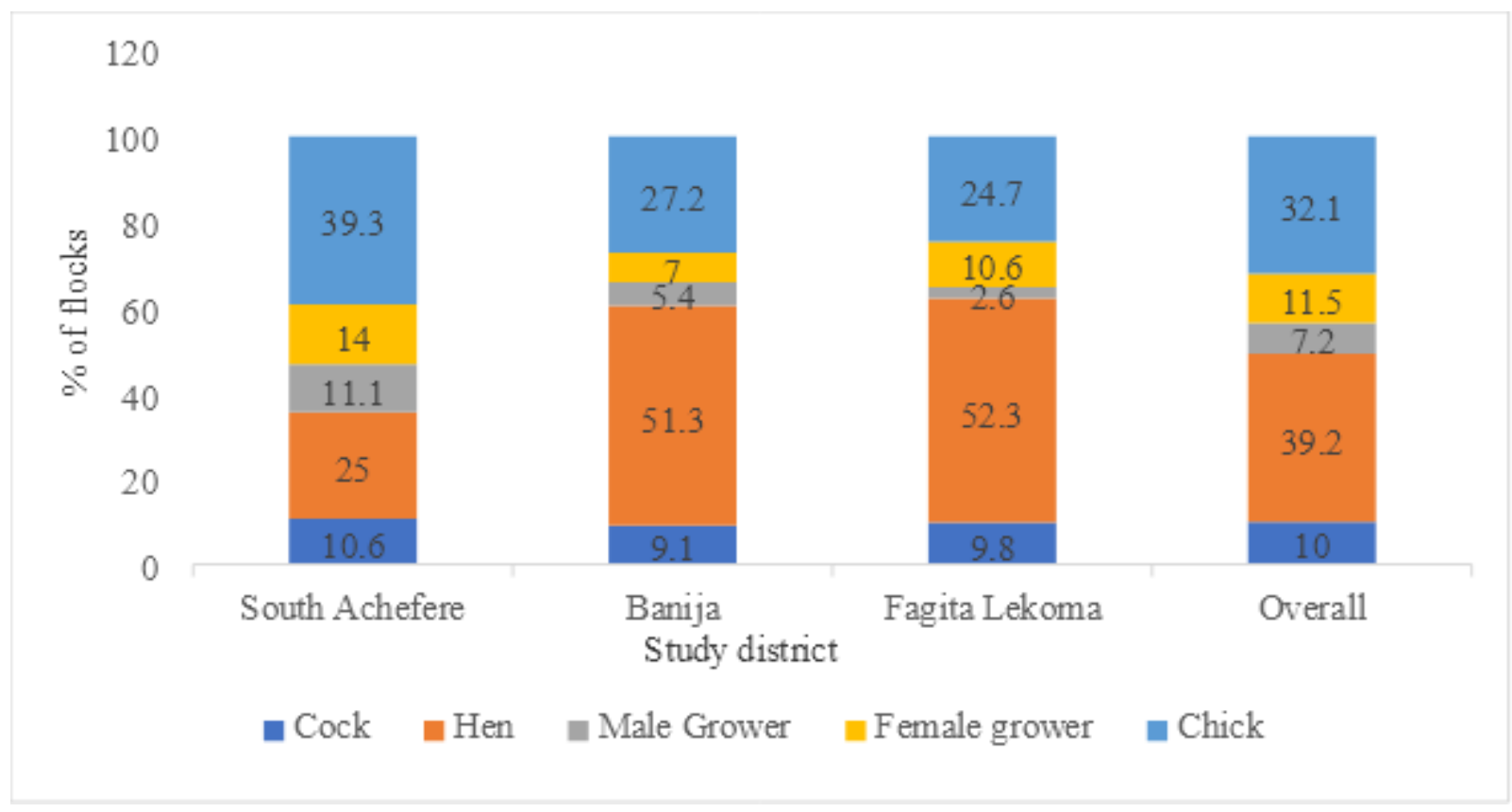

\section{Figure 1}

Percentage of chicken flock composition across the study districts 


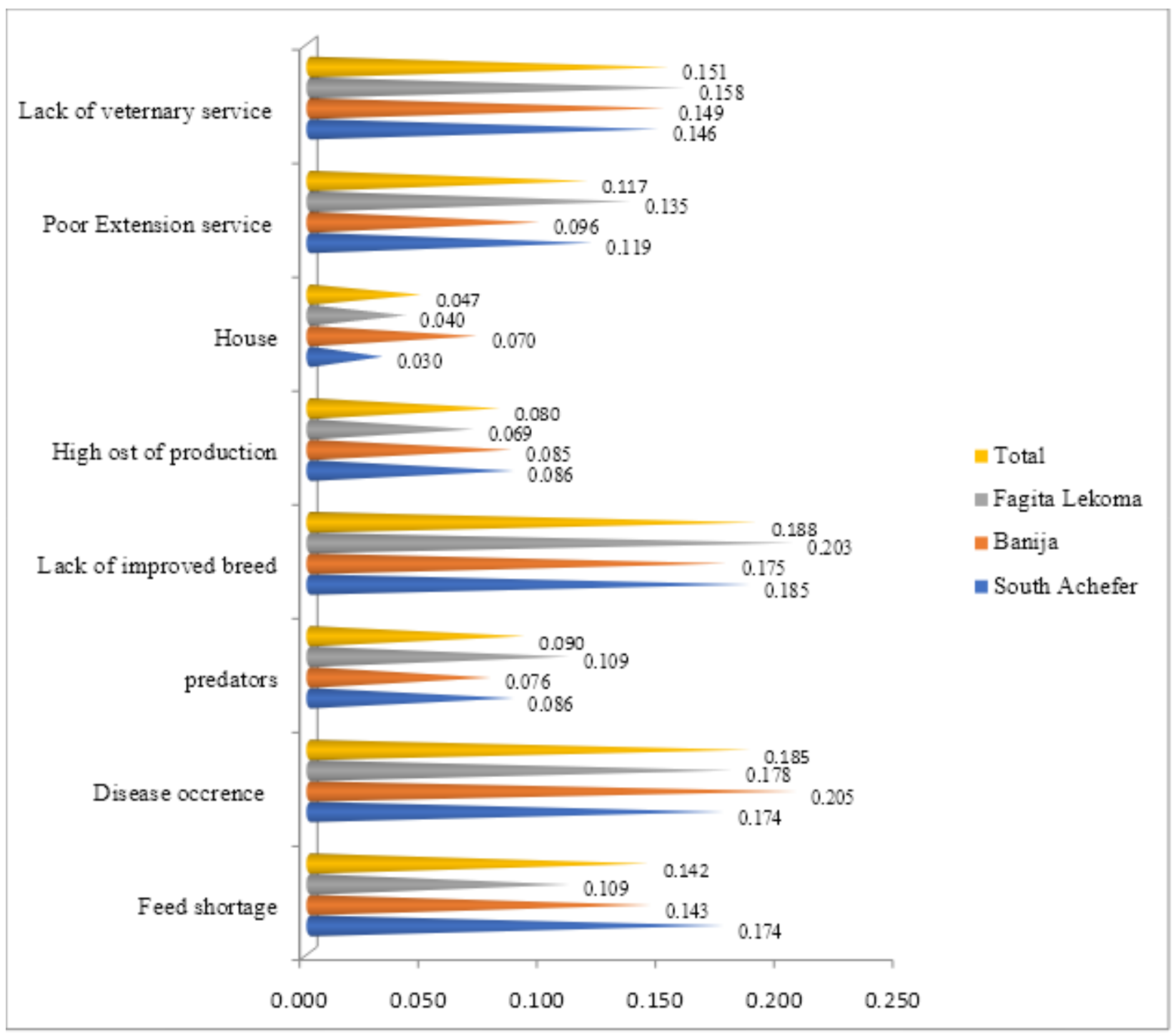

\section{Figure 2}

Index values for constraints of chicken production in the study area 